\title{
Geographical distribution, levels of infestation and population density of the mite Euvarroa sinhai Delfinado and Baker (Acarina: Mesostigmata) in Apis florea $\mathrm{F}$ colonies in Iran
}

\author{
MS Mossadegh \\ Shahid Chamran (Ahwaz) University, College of Agriculture, \\ Department of Entomology, Ahwaz, Iran
}

(Received 18 January 1989; accepted 29 January 1991)

\begin{abstract}
Summary - The geographical distribution, levels of infestation and population density of the parasitic mite, Euvarroa sinhai Delfinado and Baker, were investigated for the first time in Iran. Euvarroa sinhai was recorded from all the $A$ florea colonies that were collected as a whole colony or sampled. The mite was found up to an elevation of $1270 \mathrm{~m}$. The mite population is generally rather low in the bee colonies. The number of live Euvarroa females per 1000 worker bees was found to be 3.28 in the period from April-June when drone brood rearing is at its peak; from June-April this number increased to 5.7. The number of mites on drones at the time of emergence was $1-8$, with a mean of $4.30 \pm 1.66$. Percentage of infested drone cells in newly constructed combs with first drone generation emerged from these cells varied from $3.15-30.43 \%$, with a mean of $8.38 \%$. The female mites were phoretic from 4-10.5 months, with an average of 6.4 months on adult worker bees before entering drone cells.
\end{abstract}

Euvarroa sinhai / Apis florea / infestation rate / geographical distribution / population density / Iran

\section{INTRODUCTION}

The mite Euvarroa sinhai Delfinado and Baker is a parasite of drone brood of the honeybee Apis florea in Asia. It was first described by Delfinado and Baker (1974) as being associated with dwarf honeybee in India. Akratanakul and Burgett (1976) later identified the mite as a parasite on the drone brood of the dwarf bees in Thailand, and also observed the mite as existing only on adult drones. Koeniger et al (1983) found the adult female mites on adult worker bees in Sri-Lanka, but not on adult drones. Mossadegh and Komeili (1986) found the adult female mites on both adult worker and drone bees in addition to drone brood. This mite has been reported recently in hive debris from $\boldsymbol{A}$ mellifera colonies in India (Kapil and $\mathrm{Ag}$ garwal, 1987).

The object of the present study was to investigate the geographical distribution, levels of infestation and population density of Euvarroa in A florea colonies in Iran. $A$ florea is distributed along the entire 
southern boundary of Iran, from Beluchistan close to the border of Pakistan, along the coast of the Gulf of Oman and the Persian Gulf to Lurestan in the north west of the country. This narrow strip, beginning in the east at latitude $28^{\circ}$ and extending as far north as $34^{\circ}$ in the west, is $\approx 2000 \mathrm{~km}$ long (Ruttner et al, 1985).

\section{MATERIALS AND METHODS}

For this study, 76 colonies of $A$ florea from different bee distribution areas were examined during the period of October 1986 through August 1988. Forty-two whole colonies and samples of an additional 34 colonies were collected. Whole colonies were collected by cutting the entire nest from its substrate and shaking the bees in a container of $75 \%$ methyl alcohol (33 colonies) or placing the nest in a muslin bag for subsequent refrigeration (9 colonies). Samples of colonies were collected using an entomological forceps. The bees were put in $75 \%$ methyl alcohol for subsequent inspection. To study drone brood rearing and the number of mites on drones at the time of emergence, some $A$ florea colonies were established in the experimental apiary station. Colonies of the bees were collected in cardboard boxes and covered with muslin. Most of the colonies were collected in December and January when the bees were in winter cluster. At the other time of the year, when bees were active, water was spread by a hand sprayer on the bees before the colony was detached from its substrate. A total of 27 colonies of $A$ florea were established in the apiary during December 1986-June 1988. The number of mites on drones was counted in 2 ways: 1), drones were picked up with entomological forceps from the main colonies and were put singly in a small test tube $(10 \times 1 \mathrm{~cm}) ; 2)$, sealed brood drone comb section was cut off from the main comb, placed in $20 \times 20 \times 16-\mathrm{cm}$ boxes and kept in an incubator set at $35^{\circ} \mathrm{C}$ and $50 \pm$ $5 \% \mathrm{RH}$. Emerging drones were collected daily and placed singly in a small test tube $(10 \times 1$ $\mathrm{cm})$. All the bees were inspected under a binocular microscope (10x). Sections of sealed brood drones were also inspected for mites, their prog- eny and percentage of infested cells. The brood cells were carefully uncapped and the walls, larvae or pupae were examined carefully under a binocular microscope (10x and 14x).

For detection of mites, the soaked bees in the container were carefully shaken by hand for $10 \mathrm{~min}$ (Ritter, 1981). The contents were poured several times through a wire screen (mesh $2 \times 2$ $\mathrm{mm}$ ) to filter out the mites. Excess alcohol was passed through a cotton cloth and the mites were collected and counted. The procedure was repeated 3 times for all the samples to ensure that no mite was left on the bees.

\section{RESULTS}

Euvarroa sinhai was found in all $A$ florea colonies that were either collected as a whole colony or sampled in Iran. The mite was found up to an elevation of $1270 \mathrm{~m}$.

The mite population is generally rather low in $A$ florea colonies (table I). As 1 or 2 generations of drones are produced in the spring and sometimes 1 in the autumn, mite reproduction is limited to this time of the year. In early spring and autumn when the production of drones began, most or all of the mites were in the drone cells and none or few on the worker bees (table II). Of the 21 colonies of $A$ florea with drone brood cells which were examined, the drone brood of all colonies were infested by Euvarroa. The percentage of infested first generation drone cells in newly constructed combs varied from 3.15-30.43\% with a mean of $8.38 \%$ (table III). The infestation was identified by tiny fecal white spots in the cells.

The number of mites found on drones at the time of emergence was 1-8 with a mean of $4.30 \pm 1.66$ (tables $(V-V I)$. This was 1-2 for drones collected from the whole drone population in the colonies. When the infested newly-emerged drones were kept with uninfested newly-emerged 
Table I. Population of adult female $E$ sinhai mites in 31 whole $A$ florea colonies collected in various parts of Iran.

\begin{tabular}{|c|c|c|c|c|}
\hline \multirow[t]{2}{*}{$\begin{array}{c}\text { Date } \\
\text { collected }\end{array}$} & \multicolumn{2}{|c|}{$\begin{array}{l}\text { No of adult workers and } \\
\text { adult mites on workers }\end{array}$} & \multicolumn{2}{|c|}{$\begin{array}{l}\text { No of adult drones and } \\
\text { adult mites on drones }\end{array}$} \\
\hline & Workers & Mites & Drones & Mites \\
\hline $11-15-1986$ & 10650 & 4 & - & - \\
\hline $11-15-1986$ & 11400 & 3 & - & - \\
\hline $12-16-1986$ & 3184 & 2 & - & - \\
\hline $05-06-1987$ & 2840 & 10 & 132 & * \\
\hline $06-08-1987$ & 4409 & 10 & 24 & * \\
\hline $05-10-1987$ & 9540 & 312 & 208 & * \\
\hline $05-16-1987$ & 3150 & 22 & 82 & - \\
\hline $05-23-1987$ & 2450 & 7 & 1 & - \\
\hline 05-29-1987 & 1615 & 21 & - & - \\
\hline $05-20-1987$ & 10420 & 54 & 268 & 3 \\
\hline $06-03-1987$ & 13439 & 59 & 21 & 2 \\
\hline $07-06-1987$ & 12600 & 297 & 562 & 211 \\
\hline $10-05-1987$ & 4460 & 7 & - & - \\
\hline $10-05-1987$ & 1014 & 1 & 12 & - \\
\hline $10-05-1987$ & 8845 & 2 & 388 & 25 \\
\hline $10-26-1987$ & 15380 & 13 & - & - \\
\hline 11-04-1987 & 3800 & - & 152 & 33 \\
\hline $11-08-1987$ & 28700 & 116 & - & - \\
\hline $11-16-1987$ & 19600 & 79 & - & - \\
\hline $12-05-1987$ & 9400 & 32 & - & - \\
\hline $12-10-1987$ & 10580 & 140 & - & - \\
\hline $12-10-1987$ & 17600 & 53 & - & - \\
\hline 05-03-1988 & 19610 & 98 & 112 & * \\
\hline 05-03-1988 & 22800 & 4 & 383 & 95 \\
\hline $05-17-1988$ & 17840 & 8 & 427 & 107 \\
\hline $06-08-1988$ & 2106 & 15 & 7 & - \\
\hline $06-12-1988$ & 18950 & 15 & 449 & 260 \\
\hline $06-17-1988$ & 11500 & 52 & 40 & * \\
\hline $07-11-1988$ & 12360 & 17 & 266 & 54 \\
\hline $07-11-1988$ & 3488 & 13 & 47 & 1 \\
\hline 08-24-1988 & 7794 & 58 & 4 & - \\
\hline
\end{tabular}

" Counted with workers.

workers, many mites soon changed host at the time of feeding the drones, and were found on workers after $4 \mathrm{~h}$. There were 16 with a mean of 1.72 mites on the body of such workers after $24 \mathrm{~h}$ (table VII). The mites were found attached to the venter and dorsum of the bee's abdomen, at the scutellar region or pleural area of the thorax, between the thorax and abdomen, on the neck region, the wings and the leg bases. When the mites are attached to the bee's abdomen especially on the ventral side, they are hidden between the abdominal segments and are difficult to detect. 
Table II. Number of adult female mites on adult workers and in sealed drone cells in spring and autumn.

\begin{tabular}{rccccc}
\hline \multirow{2}{*}{$\begin{array}{c}\text { Date } \\
\text { collected }\end{array}$} & $\begin{array}{c}\text { No of adult workers and adult female } \\
\text { mites on worker bees }\end{array}$ & & \multicolumn{2}{c}{$\begin{array}{c}\text { No of adult drones and adult female } \\
\text { mites on drones }\end{array}$} \\
\cline { 2 - 3 } & Workers & Mites & & Drones & Mites \\
\hline & & & & 388 & \\
$10-5-1987$ & 8845 & 2 & & 152 & 33 \\
$11-4-1987$ & 13800 & - & & 383 & 95 \\
$5-3-1988$ & 22800 & 8 & & 427 & 107 \\
$5-17-1988$ & 17840 & 17 & & 266 & 54 \\
$6-11-1988$ & 12360 & 15 & & 449 & 260 \\
$6-12-1988$ & 18950 & & & & \\
\hline
\end{tabular}

Table III. Number and percentage of infested drone cells in 7 A florea colonies.

\begin{tabular}{ccc}
\hline $\begin{array}{c}\text { No of drone } \\
\text { cells examined }\end{array}$ & $\begin{array}{c}\text { No of } \\
\text { infested cells }\end{array}$ & $\begin{array}{c}\% \text { of } \\
\text { infested cells }\end{array}$ \\
\hline & & \\
495 & 18 & 3.63 \\
552 & 25 & 4.52 \\
730 & 23 & 3.15 \\
890 & 70 & 7.86 \\
662 & 21 & 3.17 \\
299 & 91 & 30.43 \\
152 & 9 & 5.92 \\
\hline
\end{tabular}

Examination of colony workers showed that the number of live Euvarroa females per 1000 bees was low (3.28) in the period from April-June when drone brood rearing is at its peak and many of the mites are in the sealed drone brood cells or on the adult drones; from June-April this number increased to 5.7 (table VIII).

When the hosts do not survive to become adult, many of the female mites are able to leave the cells by making a small rectangular hole in the middle of the cell cap with their mouthparts. The mite first makes a small hole with the sharp teeth of

Table IV. Daily total number of the adult female mites on emerged drones in 8 drone comb sections.

\begin{tabular}{rrrrrrrrrrr}
\hline & & & & \multicolumn{7}{c}{ Days } \\
& 1 & 2 & 3 & 4 & $5^{2}$ & 6 & 7 & 8 & 9 & 10 \\
\hline & 76 & 19 & 24 & 33 & - & - & - & - & - & - \\
& 13 & 9 & 8 & 25 & - & - & - & - & - & - \\
& 7 & - & - & - & - & - & - & - & - & - \\
& 102 & 57 & 73 & 17 & 10 & 2 & 1 & - & - & - \\
& 11 & 5 & 7 & 4 & 9 & 12 & 7 & 23 & - & - \\
& 3 & 8 & 2 & 9 & 2 & 30 & - & 8 & 20 & 2 \\
& 33 & 5 & 2 & 6 & 8 & 6 & 4 & 8 & 20 & - \\
& 10 & 17 & 154 & 15 & - & - & - & - & - & - \\
Total & 255 & 120 & 270 & 109 & 29 & 50 & 12 & 39 & 40 & 2 \\
\hline
\end{tabular}


Table V. Number of Euvarroa female mites on drones at the time of emergence in 8 drone comb sections.

\begin{tabular}{|c|c|c|c|c|c|c|c|c|c|}
\hline & \multicolumn{9}{|c|}{ Euvarroa female No } \\
\hline & 1 & 2 & 3 & 4 & 5 & 6 & 7 & 8 & 9 \\
\hline $\begin{array}{l}\text { No cases observed } \\
\text { Total No }\end{array}$ & $\begin{array}{l}323 \\
323\end{array}$ & $\begin{array}{r}64 \\
128\end{array}$ & $\begin{array}{l}25 \\
75\end{array}$ & $\begin{array}{r}9 \\
36\end{array}$ & $\begin{array}{r}4 \\
20\end{array}$ & $\begin{array}{r}5 \\
30\end{array}$ & $\begin{array}{r}2 \\
14\end{array}$ & $\begin{array}{r}2 \\
26\end{array}$ & - \\
\hline
\end{tabular}

Table VI. Number of daily Euvarroa female mites on drones at the mite of emergence in 8 drone comb sections.

\begin{tabular}{lrrrrrrrrrrr}
\hline & 1 & 2 & 3 & 4 & 5 & 6 & 7 & 8 & 9 & 10 & Total \\
\hline No of mites & 255 & 120 & 270 & 109 & 29 & 50 & 12 & 39 & 40 & 2 & 926 \\
No of drones & 108 & 79 & 106 & 49 & 20 & 25 & 10 & 13 & 21 & 1 & 433 \\
\hline
\end{tabular}

Table VII. Number of Euvarroa mite on uninfested workers kept with infested drones for $24 \mathrm{~h}$.

\section{No of mites \\ $\begin{array}{llllll}1 & 2 & 3 & 4 & 5 & 6\end{array}$}

\section{Adult workers}

No of cases observed $\begin{array}{llllll}33 & 9 & 8 & 3 & - & 1\end{array}$

her movable digit chelicera in the middle of the cap and then enlarges it sideways by pushing aside the wax. When the hole became large enough, the mite passed through it sideways and out of the cell; it took $24-48 \mathrm{~h}$ for the mites to make such a hole and leave the capped cells. Out of 99 sealed drone cells with dead pupae, 15 were found with such holes and with no live female mites in these cells. The mites left in the cells were either dead parental females or living or dead males. Many mites leave the cells when the adult drones begin to chew their cell cappings. The mites leave the cells and wander over the comb surface searching for a new cell or a carrier host.

As reported by Mossadegh and Komeili (1986), the mite spends the winter as an adult on worker bees and feeds on clusteri-

Table VIII. Number of live $E$ sinhai adult females per 1000 worker adult bees measured during November 1986-August 1988.

\begin{tabular}{ccccc}
\hline Date & $\begin{array}{c}\text { No of colonies } \\
\text { examined }\end{array}$ & $\begin{array}{c}\text { Total No of } \\
\text { worker bees }\end{array}$ & $\begin{array}{c}\text { Total No of adult } \\
\text { female mites }\end{array}$ & $\begin{array}{c}\text { No of mites per } \\
1 \text { 000 worker bees }\end{array}$ \\
\hline April-June & 12 & 116280 & 381 & 3.28 \\
June-April & 12 & 143436 & 814 & 5.70 \\
\hline
\end{tabular}


Table IX. Phoresy duration time of adult female $E$ sinhai mites on adult workers in $8 \mathrm{~A}$ florea colonies that were under constant observation.

\begin{tabular}{|c|c|c|c|c|c|c|}
\hline \multirow[t]{2}{*}{$\begin{array}{l}\text { Date of colony } \\
\text { establishment }\end{array}$} & \multirow[t]{2}{*}{$\begin{array}{l}\text { Date of drone } \\
\text { brood rearing }\end{array}$} & \multicolumn{2}{|c|}{$\begin{array}{c}\text { Nos of adult workers } \\
\text { and adult mites } \\
\text { worker bees }\end{array}$} & \multicolumn{2}{|c|}{$\begin{array}{c}\text { Nos of adult drones } \\
\text { and adult mites } \\
\text { on drone }\end{array}$} & \multirow[t]{2}{*}{$\begin{array}{l}\text { Phoresy duration } \\
\text { time }\end{array}$} \\
\hline & & Workers & Mites & Drones & Mites & \\
\hline $12-31-1987$ & $4-27-1988$ & 17840 & 8 & 427 & 107 & 4 months \\
\hline $11-22-1987$ & 5- 6-1988 & 18950 & 15 & 449 & 260 & $51 / 2 "$ \\
\hline $11-01-1987$ & 5- 5-1988 & 19610 & 98 & 112 & * & $61 / 2 "$ \\
\hline $11-26-1987$ & $5-25-1988$ & 13500 & 6 & 395 & 76 & $61 / 2 "$ \\
\hline $11-27-1987$ & 5-29-1988 & 11500 & 52 & 40 & * & $61 / 2 "$ \\
\hline $11-28-1987$ & $5-25-1988$ & 12360 & 17 & 266 & 54 & $61 / 2 "$ \\
\hline 10-16-1987 & $5-12-1988$ & 22800 & 4 & 383 & 95 & $71 / 2 "$ \\
\hline 5-29-1987 & 4-18-1988 & 20340 & 9 & 466 & 266 & $101 / 2 \quad "$ \\
\hline
\end{tabular}

- Counted with workers.

ng bees during the cold season when brood rearing has ceased. More information was obtained on phoresy of the adult female mites in the course of this investigation. It was found that the mite, in colonies that were under constant observation, can spend from 4-10.5 months with an average of 6.38 months on worker bees before entering drone cells (table IX).

The male mites do not die soon after mating in the sealed brood cells. $78.74 \%$ of a total of 127 males in 99 sealed drone cells were found alive; up to 3 live male mites were found in a single cell. The bees in the pupal stage were dead in these cells, but had not dried. Some of these cells were uncapped up to $13 \mathrm{~d}$ after the last drone had emerged from the comb. All live female mites in these cells had swollen bodies and were ready to lay eggs.

\section{DISCUSSION}

The life cycle of $E$ sinhai is similar to that of Varroa jacobsoni Oudemans, ie, the mated female enters the cell of a late larval bee prior to capping, and attaches her eggs to developing bee larva or pupa. All stages live inside the capped brood cells of the bee host, and only the adult female mites leave the cells (Akratanakul, 1976). The mite reproduces on drone brood and apparently does not enter worker brood cells.

As drone brood rearing is limited both in quantity and period of time, the mite population is low in A florea colonies. Infestation of drones is always higher at the time of their emergence, but is reduced within $24 \mathrm{~h}$. Infestation of the adult worker bees is 
higher when there is no drone brood in colonies.

This study also demonstrates that the adult female mites are phoretic on adult workers and feed on bees when drone brood rearing is absent in the colony. As soon as the brood rearing starts, the mites enter the cells and reproduction begins.

Résumé - Répartition géographique, niveaux d'infestation et densité de population de l'acarien Euvarroa sinhai Delfinado and Baker dans des colonies d'Apis florea F en Iran. Pour la première fois ont été étudiés en Iran la répartition géographique, les niveaux d'infestation et la densité de population de l'acarien parasite Euvarroa sinhai. Euvarroa était présent dans les 76 colonies d'A florea prélevées en totalité ou échantillonnées. Il a été trouvé jusqu'à $1270 \mathrm{~m}$ d'altitude. La population d'acariens était généralement assez faible (tableau I). Entre avril et juin, période pendant laquelle l'élevage du couvain est à son maximum, le nombre moyen de femelles d'Euvarroa était de 3,28 par 1000 ouvrières d'abeilles. De juin à avril il est passé à 5,7 (tableau VIII). Le nombre d'acariens présents sur les mâles d'abeilles au moment de l'émergence a varié de 1 à 8 (moyenne 4,30 1,66 ). Le pourcentage de cellules de mâles infestées dans les rayons nouvellement construits à l'émergence de la première génération de mâles a varié entre 3,15 et $30,43 \%$ (moyenne $8,38 \%$ ) (tableau III). Les acariens femelles sont phorétiques (restent sur les abeilles adultes) durant 4 à 10 mois et demi (moyenne 6,4 mois) avant de pénétrer dans les cellules de mâles.
Euvarroa sinhai / Apis florea / taux de parasitisme / densité de population / répartition géographique / Iran

\section{Zusammenfassung - Geographische} Verbreitung, Befallsgrad und Populationsdichte der Mllbe Euvarroa sinhal bei Völkern von Apis florea Im Iran. Zum ersten Mal wird hier über geographische Verbreitung, den Befallsgrad und die Populationsdichte der parasitischen Milbe Euvarroa sinhai Delfinado \& Baker im Iran berichtet. Euvarroa sinhai wurde bei allen Völkern von Apis florea gefunden, die entweder als ganzes Volk oder als Probe untersucht wurden. Die Milbe wurde bis zu einer Höhe von $1270 \mathrm{~m}$ gefunden. Die Population war in den Bienenvölkern im allgemeinen ziemlich klein (Tabelle I). In der Zeit zwischen April und Juni, wenn sich die Drohnenaufzucht am Höhepunkt befindet, wurden im Durchschnitt 3.28 lebende Euvarroa-Weibchen pro 1000 Arbeitsbienen gefunden. Zwischen Juni und April stieg diese Zahl auf 5.7 (Tabelle VIII). Die Zahl der Milben, die sich zur Zeit des Schlüpfens auf Drohnen befanden, schwankte zwischen 1-8 mit einem Mittelwert von $4.30 \pm 1.66$.

Der Anteil befallener Drohnenzellen in neugebauten Waben mit der ersten ausschlüpfenden Drohnengeneration schwankte zwischen $3.15 \%$ bis $30.43 \%$ (Mittel 8.38\%) (Tabelle III). Die weiblichen Milben waren zwischen 4 bis 10.5 Monate phoretisch (dh auf erwachsenen Bienen ansitzend) mit einer mittleren Dauer von 6.4 Monaten, bevor sie in Drohnenzellen eindrangen. 
Euvarroa sinhai / Apis florea / Befallsgrad / geographische Verbreltung / Populationsdichte $/$ Iran

\section{REFERENCES}

Akratanakul P (1976) Biology and systematics of bee mites of the family Varroaidae. MS thesis, Oregon State Univ, Corvallis, OR, pp 64

Akratanakul P, Burgett M (1976) Euvarroa sinhai Delfinado and Baker (Acarina: Mesostigmata) a parasitic mite of Apis florea. J Apic Res 15, 11-13

Delfinado M, Baker EW (1974) Varroidae: a new family of mites on honeybees (Mesostigmata: Acarina). J Wash Acad Sci 64, 4-10
Kapil RP, Aggarwal K (1987) First record of $E$ sinhai from Apis mellifera colonies. Bee World 68(4), 189

Koeniger N, Koeniger G, Delfinado-Baker $M$ (1983) Observation on mites of the Asian honeybee species (Apis cerana, Apis dorsata, Apis florea). Apidejogie 14, 197-204

Mossadegh MS, Kameili Birjandi A (1986) Euvarroa sinhai Delfinado and Baker (Acarina: Mesostigmata): a parasitic mite on Apis florea F in Iran. Am Bee J 126, 684-685

Ritter W (1981) Varroa disease of the honeybee Apis mellifera. Bee World 62(4), 141-153

Ruttner F, Pourasgher D, Kauhausen D (1985) Die Honigbienen des Iran. I. Apis florea Fabricius. Apidologie 16(2), 119-138 